\title{
Review of ten-years presence of Aedes albopictus in Spain 2004-2014: known distribution and public health concerns
}

\author{
Francisco Collantes ${ }^{1 *}$ DD, Sarah Delacour ${ }^{2}$, Pedro María Alarcón-Elbal ${ }^{2}$, Ignacio Ruiz-Arrondo², \\ Juan Antonio Delgado', Antonio Torrell-Sorio ${ }^{3}$, Mikel Bengoa $^{2}$, Roger Eritja ${ }^{4}$, Miguel Ángel Miranda $^{5}$, \\ Ricardo Molina ${ }^{6}$ and Javier Lucientes ${ }^{2}$
}

\begin{abstract}
Ten years have gone by since the Asian tiger mosquito Aedes albopictus was recorded for the first time in Spain. In this paper, all relevant published information about this vector in Spain for the period 2004-2014 is reviewed. The known distribution for 2014 is provided, including all historical records (published and unpublished data) and the results from samplings of the last year. The consequences on public health about the presence of the Asian tiger mosquito in Spain are also highlighted. Further, legal aspects and control plans related to the management and diseases transmitted by this invasive vector species are also discussed.
\end{abstract}

Keywords: Aedes albopictus, Spain, Vector-borne diseases, Chikungunya, Dengue, Vector map, Review

\section{Background}

Aedes albopictus (Skuse, 1894) (Diptera; Culicidae) is an invasive species whose first detection in Europe occurred in Albania in 1979 [1]. At present, this species has been recorded in 22 countries of Europe, even if it is considered established only in 15 as a result of different and continuous arrivals [2].

In 2004, this species was recorded in Spain for the first time [3] and ten years after that it was founded in almost all Mediterranean Spanish coast, as it is shown in this work.

The objective of this review is to compile all published information about Aedes albopictus for Spain and update the known distribution of this vector in Spain until 2014. In this way, we deal with all information about distribution but, in addition, we review other related aspects with perspectives of public health impact, legal situation and control measures.

\section{Review}

\section{Arrival of Aedes albopictus to Spain}

Although the source of arrival to Spain remains unknown, the historical entrance to the neighbouring

\footnotetext{
*Correspondence: fcollant@um.es

'Departamento de Zoología y Antropología Física, Facultad de Biología,

Universidad de Murcia, Murcia, Spain

Full list of author information is available at the end of the article
}

country, France, is well documented. The first detection was in used tyres storage centres in the north of France in 1999 [4] and successive years 2002, 2004 and 2006, being originated from international trade of used tyres from USA [5]. However, nowadays the main established populations are in the Mediterranean France, where Ae. albopictus was recorded for the first time in 2004 [5]. At that time, the risk of introduction to Spain from France was considered to be high [6] and the EVITAR network (network for the study of viruses transmitted by arthropods and rodents financed by the Spanish Ministry of Health) included the surveillance of this species as a priority. In this sense, a thoroughly surveillance conducted in used-tyres storage centres from 2003 to 2004 did not show its presence [7]. Nevertheless in 2004, an increase on residents complains about insect bites was recorded in Sant Cugat del Vallès (Baix Llobregat, Catalonia). An entomological study conducted in the area showed the presence of Simulium ornatum (Meigen, 1818) and, for the first time in Spain, also the presence of Ae. albopictus $[3,8]$. It is highly probable that $A$ e. albopictus was in the area at least during the two previous years, based on the records about biting incidence on the residents [8]. As we have noticed in our regular fieldwork, the resident's 
perception about the presence of the tiger mosquito begins when it is already established for one to two years.

\section{Surveillance and known distribution in Spain till 2014 Surveillance in Spain: history and situation}

It is worth mentioning that the majority of the Spanish territory has not been systematically surveyed yet and the positive areas have not been continuously monitored. There was not and there is not, at present, any initiative at country level to coordinate the different programs and projects about surveillance of tiger mosquito. After the first detection in 2004, several occasional studies, some of them extensive but never systematic, have been carried out to find Ae. albopictus in Spain.

Because Catalonia was the first colonized and most affected region, the sampling has been more intense and continuous and several local institutions have contributed to the surveillance, namely: Generalitat de Catalunya, Servei de Control de Mosquits del Consell Comarcal del Baix Llobregat, Agència de Salut Pública de Barcelona and Servei de Control de Mosquits de la Badia de Roses $i$ Baix Ter [9-13]. The Valencian Community (located south of Catalonia) has been also repeatedly sampled by different research groups. The research team of the Univerisity of Valencia have provided some isolated records and opinion articles about Ae. albopictus [14-23].

In addition, the Spanish Ministry of Health, Social Services and Equality [Ministerio de Sanidad, Servicios Sociales e Igualdad] has sponsored since 2007, the contract "Entomological surveillance at airports and ports against imported vectors of exotic infectious diseases and surveillance of potential indigenous vectors of such diseases", which has enhanced the surveillance of Ae. albopictus in important ports and airports of mainland Spain, as well as in the Balearics and Canary Islands, and the Spanish Mediterranean side, exclusive Catalonia [24-34].

The majority of the above mentioned active surveillance has been conducted by means of oviposition traps (ovitraps) and to a lesser extent, by using BG-Sentinel ${ }^{\mathrm{Tx}}$ traps (Biogents AG, Regensburg, Germany), CDC-type light traps, larval sampling and human landing caches. However, no comparison of the efficacy of the different methods has been conducted in Spain. The use of standardise methods, either for detection and monitoring of invasive mosquitoes species, at national and international level (i.e.: EU), appears as an appealing challenge for researchers and public health officers. As an example, current research groups in Spain use different types of ovitraps (different in volume and size of opening), as well as different density of traps and sampling frequency. Except for the first detection of the Asian tiger mosquito in Balearic Islands [32] and some parts of Catalonia, the European Centre for Disease Prevention and Control
(ECDC) guidelines [35] and WHO-EMCA guidelines [36] have not been followed for the rest of Spain.

In addition to active surveillance, an innovative passive mosquito surveillance based on citizen's observations has been developed in Spain in similar way to other countries in Europe [37]. The project AtrapaelTigre.com ("hunting the tiger") allows non-expert residents to upload, by means of a phone application, pictures of mosquitoes linked to a geo-referenced locality. Afterwards, those pictures are validated by experts that indicate the potential presence of Ae. albopictus in the locality, which will be confirmed by means of field sampling. Thanks to this project an unexpected isolated population in the Malaga province was detected and the Andalusia region was included in the list of colonised areas [27]. The ECDC [38] recommends to include this type of initiatives in the plans of mosquitoes control.

\section{Known distribution till 2014}

In this section, we have compiled information about all Spanish municipalities where Ae. albopictus has been recorded from 2004 to 2014. The data have been originated from published studies, unpublished data of surveillance made from the Catalonian administration and the results from 2014 of the above mentioned "Entomological surveillance at airports and ports against imported vectors of exotic infectious diseases and surveillance of potential indigenous vectors of such diseases". The field studies were done under the with institutional, regional and national guidelines/laws and special approbations for ethics committees were not necessary.

From 2004 to 2014, Ae. albopictus has been recorded in 470 municipalities belonging to 13 provinces from six autonomous communities in Spain (Table 1, Fig. 1), highlighting the recent addition, in 2014, of 2 regions and four provinces (Andalusia: Málaga, Granada and Almería; Basque Country: Guipuzcoa). The record in Maials (Lleida province, Catalonia), in 2008 [10], is considered as an sporadic record, since only adults were recorded once (in a tyre dump which was subsequently disinsected), and not established populations were detected in subsequent years. The very recent finding in the Basque Country [15], considered as an early detection, has lead to set up an intensive surveillance in this area to check for population establishment and the undesirable starting of the colonisation of the Spanish Atlantic side.

During the last ten years, a remarkable rise of the $A e$. albopictus distribution, mainly in Catalonia and Valencia Community, of mainland Spain has occurred (Figs. 2 and 3). It has not only increased, but an acceleration of the process has been observed. The historical records for every municipality, with their references as well as the new records are shown in the Additional file 1: 
Table 1 Resume of positive municipalities recorded for Aedes albopictus in Spain. The record in Lleida (Maials, 2008) is considered as an sporadic record

\begin{tabular}{|c|c|c|c|c|c|c|c|c|c|c|c|c|c|c|c|c|c|}
\hline \multirow[b]{2}{*}{ Record year } & \multicolumn{5}{|l|}{ Catalonia } & \multicolumn{4}{|c|}{ Valencian Community } & \multicolumn{2}{|l|}{ Balearic Islands } & \multirow{2}{*}{$\begin{array}{l}\text { Region of Murcia } \\
\text { Murcia }\end{array}$} & \multicolumn{3}{|c|}{ Andalusia } & \multicolumn{2}{|c|}{ Basque Country } \\
\hline & Barcelona & Girona & Lleida & Tarragona & $\mathrm{T}$ & Castellón & Valencia & Alicante & $\mathrm{T}$ & Balearic/Majorca & Balearic/lbiza & & Almería & Granada & Málaga & Guipúzcoa & $\mathrm{T}$ \\
\hline 2004 & 2 & & & & 2 & & & & 0 & & & & & & & & 2 \\
\hline 2005 & 8 & & & 1 & 9 & & & 1 & 1 & & & & & & & & 10 \\
\hline 2006 & 17 & & & & 17 & & & & 0 & & & & & & & & 17 \\
\hline 2007 & 27 & & & & 27 & & & & 0 & & & & & & & & 27 \\
\hline 2008 & 24 & 5 & 1 & 4 & 34 & & & & 0 & & & & & & & & 34 \\
\hline 2009 & 28 & 7 & & 2 & 37 & & & 1 & 1 & & & & & & & & 38 \\
\hline 2010 & 37 & 2 & & 11 & 50 & 1 & & & 1 & & & & & & & & 51 \\
\hline 2011 & 23 & 28 & & 19 & 70 & 1 & & 2 & 3 & & & 1 & & & & & 74 \\
\hline 2012 & 18 & 8 & & 20 & 46 & 5 & & 4 & 9 & 5 & & 2 & & & & & 62 \\
\hline 2013 & 10 & 1 & & 11 & 22 & 15 & 4 & 11 & 30 & 2 & & 3 & & & & & 57 \\
\hline 2014 & 15 & 18 & & 25 & 58 & 1 & 10 & 9 & 20 & 5 & 1 & 8 & 2 & 2 & 1 & 1 & 98 \\
\hline Total & 209 & 69 & 1 & 93 & 372 & 23 & 14 & 28 & 65 & 12 & 1 & 14 & 2 & 2 & 1 & 1 & 470 \\
\hline
\end{tabular}




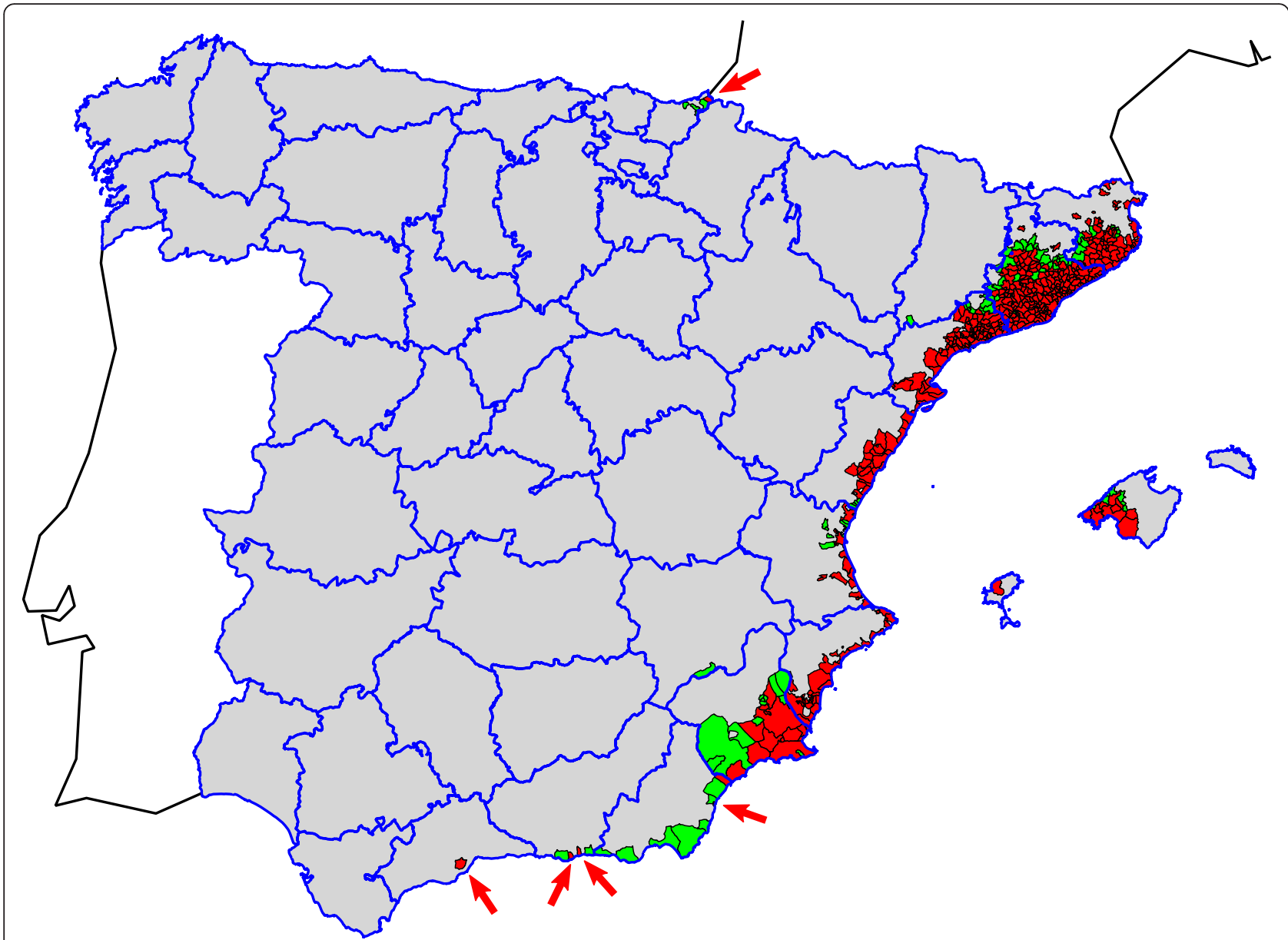

Fig. 1 Known distribution of Aedes albopictus in Spain in 2014. Red: recorded in municipality; Green: not recorded; Gray: not studied. The arrows mark small positives isolates municipalities

Appendix and Fig. 4. Furthermore, Ae. albopictus was not detected in the provinces of Zaragoza (airports) and Huelva, where other mosquitoes are routinely sampled, but specific methods for tiger mosquito, such as ovitraps, are not used.

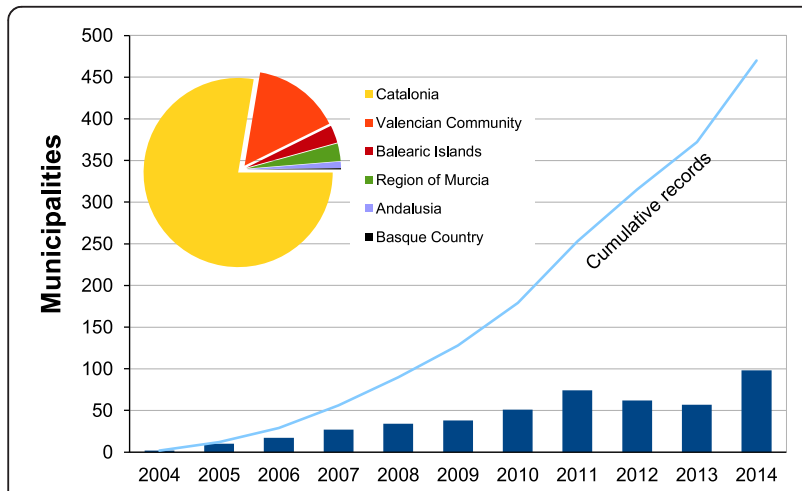

Fig. 2 Evolution and amount of positive recorded municipalities for Aedes albopictus per year in Spain 2004-2014. Line:

Cumulative records
In regards to the Spanish archipelagos, Ae. albopictus has been recorded from Majorca [32] and Ibiza [34], whereas it is absent in the Canary Islands where an active surveillance is carry through in ports and airports of Gran Canaria, Tenerife and La Palma, since 2013 [39].

Because the majority of Spain has not been studied yet, as it is said above, we believe the known distribution, shown in the present work, could easily extend in the next years. During these ten years, several risk models based on climatic factors have propounded maps for Europe where areas of the Southern Spain would be less suitable to be colonised (even $0 \%$ of suitability in some models) by Ae. albopictus [2]. However, over the last decade, Ae. albopictus was detected, firstly in some isolates areas until it has colonized almost all the Spanish Mediterranean Arch, from Northern Catalonia to Málaga. As Collantes et al. [40] pointed out in 2014, these risk models have included mainly climatic macrovariables, such as precipitation. Other variables, such as social ones, are generally not considered in the models, for example, water-saving culture due to usual drought in 

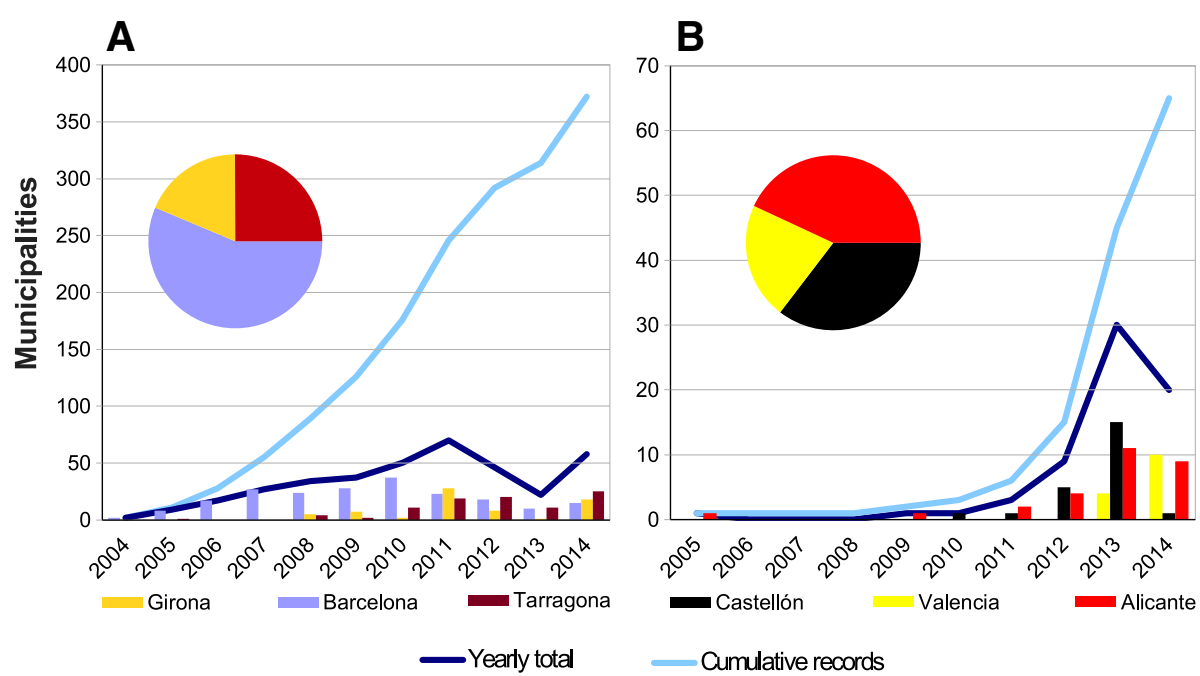

Fig. 3 Evolution and total amount of positive recorded municipalities for Aedes albopictus per year in Spain. a Catalonia 2004-2014; the record in Lleida (Maials, 2008) is not included due to it is considered as an sporadic record. b Valencian Community 2005-2014

Southern Spain, makes available numerous artificial containers that are larval habitats for Ae. albopictus regardless precipitation. Roche et al. [41] included the land use (social variable) in the recent study of spread of this vector in France, which is an important factor of prediction of establishment.
The sequence of occupation of Ae. albopictus, since its detection in Catalonia in 2004, shows a pattern of colonisation from the coastal area to inland in mainland (Fig. 4), which could fit with a diffusion process. However, some jump dispersals have been observed in other areas. The first and best known happened in Orihuela municipality

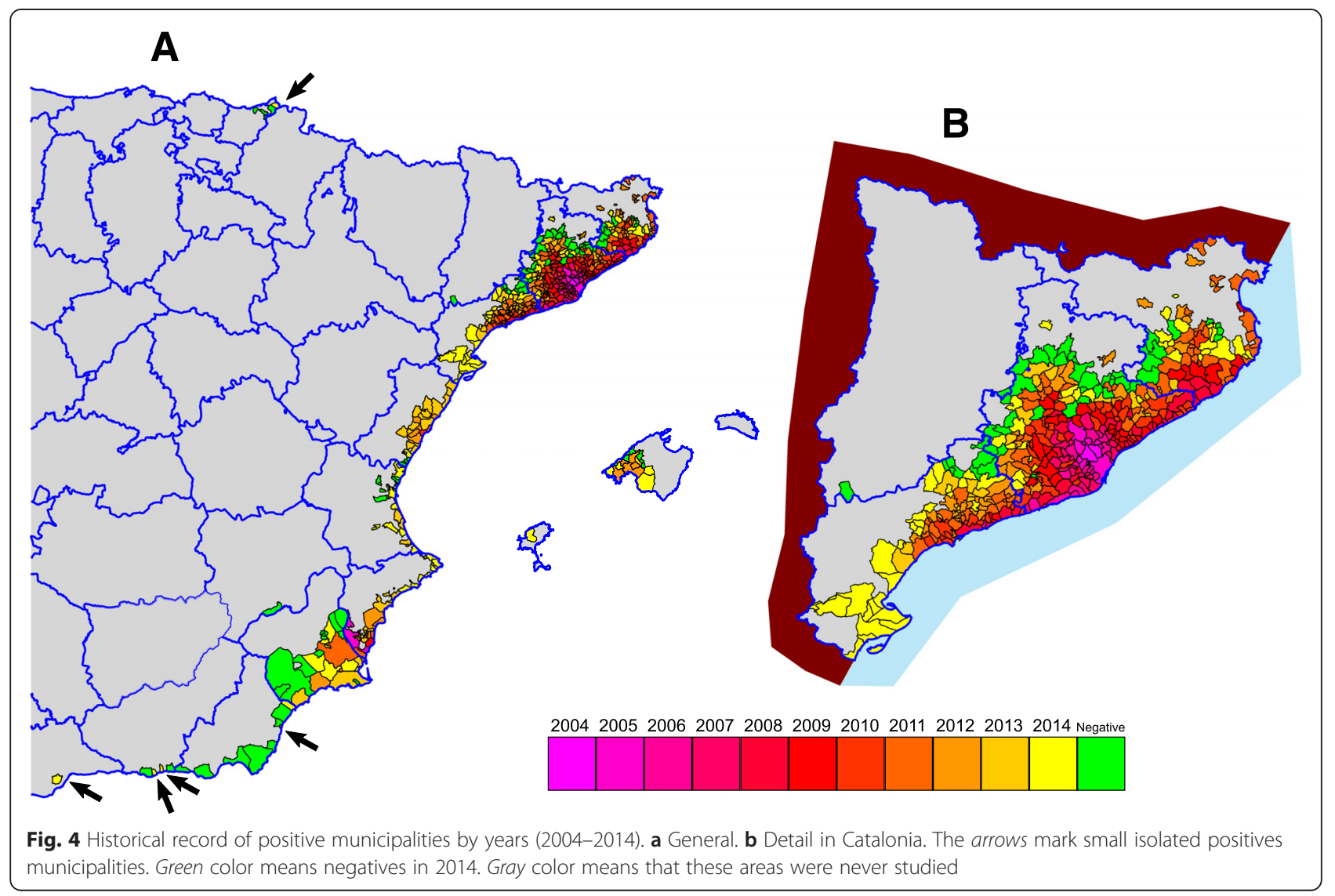


(Valencian Community), which is located almost $500 \mathrm{~km}$ from the contemporary foci of Catalonia [11]. The owner who found and identified the tiger mosquito in her vacation house was resident in Sant Cugat del Vallès, one of the first recorded localities in Spain. For this reason, it was speculated about the importance of the passive transport inside cars, and it was taken into account the surveillance around the highway A-7, the major road which runs along the Spanish Mediterranean coast, based on the hypothesis from Moore \& Mitchell [42] in USA. Recently in France, Roche et al. [41] assumed this hypothesis too and they found dispersal jumps but considered that the most of them have not started new fronts, though the temporal sequence of positives departments in France shows gaps between them (http://ecdc.europa.eu/en/healthtopics/ vectors/vector-maps/Pages/VBORNET_maps.aspx).

Some details about the environmental variability of known distribution of tiger mosquito in Spain can be pointed to. It has been found in a broad altitude range. There are many points almost at sea level and the highest records were in the Castellterçol $(713 \mathrm{mSL})$ and Berga (702 mSL) municipalities (Barcelona, Catalonia).

At the moment, studies to infer correlation between environmental factors and the distribution of Ae. albopictus have not been published in Spain and the inadequate budgets have been channelled towards sampling from anthropized/urbanized areas. Now, some of us are currently involved in a project with this objective.

In the same sense, due to meagre budgets, only in some areas, continuous surveillance has been carried out. The longest record is from Catalonia but some data of seasonality has been also recorded in parts of the Balearic Islands and the Region of Murcia. Because the ovitraps sampling has been the most used method in Spain, we have not got direct data of density. But, as some authors have already pointed out (Facchinelli et al. 2007, Abramides et al. 2011, etc.), it could be inferred from the oviposition catches or the number of positive points since there is correlation between the number of positives and the number of eggs in the same date: $R^{2}=$ 0.94 (Cartagena); $R^{2}=0.92$ (Majorca). These pseudo phenologies are shown in Fig. 5: General phenology in Catalonia (the number of municipalities has changed along this period) from data of the Generalitat de Catalunya, between 2005-2014; phenology of Baix Llobregat (Barcelona province) from data of Consell del Baix Llobregat. From this pair of datasets, the first captures in Catalonia are placed on the $17^{\text {th }}$ week of the year and the last one on the $78^{\text {th }}$ week. Only for 2014, we have got almost the full annual cycle from Balearic Islands (Majorca) and Region of Murcia (Cartagena municipality). In Majorca the first and last records were on 4/VI/ 2014/ and 3/XII/2014. In Cartagena and another point of the region (in Murcia municipality [40]) we found a few positives samples with few eggs or larvae even in wintertime.

When comparing the four curves, the population peaks shift to the end of year in the southern places, although the first appreciable increase (not the first record of the year) is near of the middle of May for all.

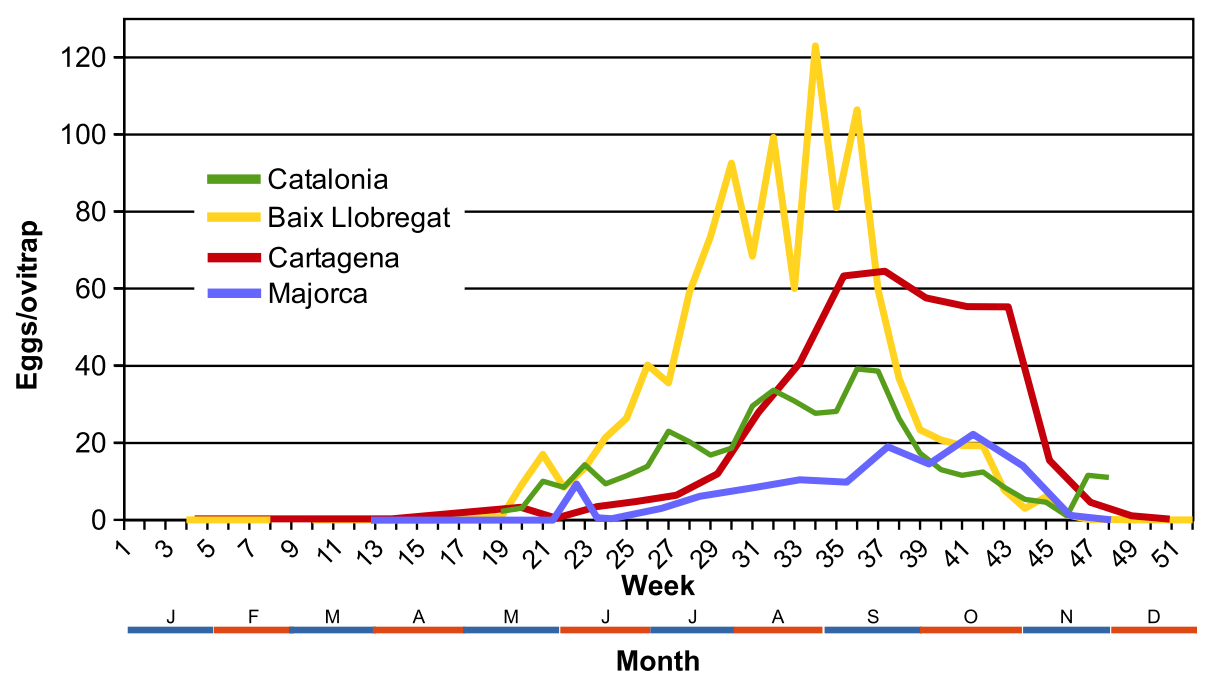

Fig. 5 Pseudo phenology of Aedes albopictus as eggs/ovitrap along the time (weeks of year). Catalonia: Data from the Generalitat de Catalunya; mean number of eggs/ovitrap from positive municipalities in the same week of the year (2005-2014). Baix Llobregat: Data from the Consell del Baix Llobregat (2006-2014); mean number of eggs/ovitrap in the same week of the year. Cartagena: number of eggs/ovitrap from positive localities in 2014, in the municipality of Cartagena (Region of Murcia). Majorca: number of eggs/ovitrap from positive localities in 2014, in the island of Majorca (Balearic Islands) 


\section{Public health impact}

Aedes albopictus is a daytime biting mosquito and shows an aggressive anthropophilic behaviour. In Barcelona, it was found $100 \%$ of anthropophilic preference for Ae. albopictus after analysing the origin of ingested blood [43]. In addition, this species also bites other vertebrates, depending on hosts availability, thus enhancing the transmission of zoonoses when acting as a bridge between animals and humans [44-46]. Obviously, this marked feeding preference has important consequences for the public health. To date, 27 arboviruses belonging to 5 families [47, 48], as well non-identified flaviviruses [49], have been isolated from Ae albopictus. Although its vector role is uncertain for the majority of them, the tiger mosquito has been clearly demonstrated as vector of dengue (DENV) and chikungunya (CHIKV) viruses [48]. In fact, Ae. albopictus was responsible of the recent European autochthonous cases of dengue in France (2010, 2013, 2014) and Croatia (2010) $[1,50]$, as well as chikungunya in Italy (2007) and France $(2010,2014)[1,51]$. Also, this species is vector of both species of nematodes Dirofilaria repens Railliet \& Henry, 1911 and D. immitis (Leidy, 1856) $[44,52]$.

The last cases of autochthonous dengue in Spain occurred in the first half of the twentieth century and they were associated to the presence of Aedes aegypti (L., 1762) [53]. In 2013, the Spanish Centre for Health Alerts and Emergencies [Centro de Coordinación de Alertas y Emergencias Sanitarias (CCAES)] issued a risk analysis about dengue [53] and concluded that the risk of local transmission in Spain would be low. However, imported cases of dengue were recorded in almost all autonomous communities of Spain. Geographically, the highest amount of cases was reported from Catalonia and Madrid, followed by Basque Country and Valencian Community. Moreover, the maximum number of cases was reported during August and September. From 2004 to 2014, the highest number of imported cases peaked in 2010, in coincidence with the observed maximum of cases in the countries of origin at that time [54]. Imported cases of dengue pose a risk of local transmission in Spain, as was already mentioned for France. Catalonia is the region were both the higher number of imported cases and the widest distribution of Ae. albopictus have been reported, thus showing the higher risk of local transmission of dengue. Besides that, the distribution of Ae. albopictus is currently expanding from year to year (Fig. 4), increasing even more the risk of local transmission.

In regards to chikungunya, imported cases from India into Spain are more recent $(2006)$ and scarce $[55,56]$. Beside that, the numerous cases of chikungunya reported from the Caribbean in 2013 [57] supposed an increase of imported cases into Spain [56, 58]. Also due to the health alert declared in France [59], a rapid risk assessment about chikungunya was conducted in Spain. The risk level was considered as medium due to the numerous cases in the Caribbean Islands, the high frequency of flights connections between both regions and the presence of Ae. albopictus in Spain, however, no autochthonous cases have been detected to date. The cumulative number of confirmed cases of imported chikungunya into Spain was 266 in 2014, most of them (96 \%) from Latin America, mainly from the Dominican Republic (69 \%). 70 of these confirmed cases were detected in Catalonia, where Ae. albopictus is well established. This is a growing concern from the point of view of public health [60].

Winter activity of Ae. albopictus adults is another important aspect when considering the risk of local transmission in Spain. In Southern Spain, Collantes et al. [40] recorded, for the first time in Spain the winter reproductive activity of adults. These findings possess important epidemiological consequences, mainly due to the increase of population dispersal and the active period for local transmission. Then, temperature could be less important as limiting factor for colonisation in this latitude than in northernmost areas, and others factors, as water availability, could become more relevant.

In Spain, the epidemiological surveillance of notifiable diseases is regulated by the Spanish law 2210/ 1995 [61]. Neither dengue nor chikungunya were included in the original list of 1996. In 2013, a new catalogue for notifiable diseases [62] was updated to be used by the Spanish Epidemiological Surveillance Network [Red Nacional de Vigilancia Epidemiológica (RENAVE)]. The protocols for chikungunya fever, dengue and West Nile virus diseases were included, however, the list of notifiable diseases was not legally updated until March 2015 [63]. In consequence, there was a period of two years (2013-14) when imported cases of dengue and chikungunya could be underestimated due to the lack of a legal framework for arthropod borne notifiable diseases.

Finally, no autochthonous cases of dengue or chikungunya have been detected in Spain. Apart of underreporting due to sub-clinic courses, two hypotheses could be formulated but remain unsolved yet. The number of imported cases is low in Spain (1); the density of mosquitoes is still low (2). In Spain, there were less imported cases than France, where authochtonous cases of chikungunya have occurred. Although, the number of imported cases has been correlated with the number of autochthonous cases of dengue in Brazil and Australia $[64,65]$, the last autochthonous cases of chikungunya in France come from a primary case with African origin, even if the imported cases from the Caribbean represent $90 \%$ of total detected in France [51].

About the relationship between density of vectors and health risk, all samplings conducted in Spain are mostly absence/presence ones, which means that there is no 
abundance maps available from the different Spanish regions where Ae. albopictus is established. As it is said above, the usual methodology of sampling has been by ovitraps in non standardised nor systematic way, so it is difficult to assign population densities in the studied areas. Therefore, it is difficult to link risk of transmission with mosquito density in areas where imported cases are frequently detected. However, for dengue, the relationship between vector density and transmission has not been sufficiently established or known neither and it is possible that transmission could occur under low densities of vector if the human population immunity (to this disease) is low [66].

At present, the health impact of Ae. albopictus in Spain is restricted to the biting nuisance. Several studies have shown that the mosquito nuisance affects to health (even without diseases transmission), quality of life and economy [67-69]. In Spain, few studies on this subject have been carried out. The biting incidence was studied after the first detection in Spain [70, 71], showing a raise of health and social problems as, for example, raise of bites and lesions, reduction of quality of life, disputes between neighbours and public unrest. Guasch [72] tried to quantify the economic impact of the biting nuisance in the municipality of Rubí (Barcelona, Catalonia) by means of the Choice models methodology (Choice experiment: Willingness to pay (WTP)). This study concluded that $60 \%$ of interviewees would accept to pay the highest amount proposed, $10 €$ by year, to reduce the populations of Ae. albopictus.

\section{Legal situation of interventions on Aedes albopictus}

The Asian tiger mosquito is an invasive exotic species and its presence in Spain is regulated by the Spanish law on invasive species [73]. This legal framework has two remarkable consequences. First, despite its health implications, the responsibility for its control lays on environmental authorities instead of health authorities. Second, the law forbids or limits its capture, possession, transport and commerce. Then, in a strictly legal framework, a special permission from environmental authorities is required for any intervention related to Ae. albopictus, as for example sampling and control measures. Legally, the Asian tiger mosquito requires an environmental management plan in order to reduce its impact and presence, as other introduced species such as the zebra mussel (Dreissena polymorpha Pallas, 1771). Unfortunately, to date there is not any national strategy for reducing the populations and dispersal of Ae. albopictus in Spain. But, we should bear on mind that according to the "One Health" approach, environmental management of invasive vector mosquito species is a key issue in public health concerns [74].

Regarding to the responsibility of controlling mosquito populations in public places in Spain, the municipalities are usually in the front line, but the legal basis of this competence is not clear or explicit, and only ambiguous references are made to "obligation to maintain the public health" in some Spanish, national and regional, laws. Some municipalities in provinces such as Barcelona, Castellón and Murcia, have adopted local ordinances which encourage residents to reduce larval habitats as well as to control Ae. albopictus populations in private properties. In Catalonia, there is also a proposal of bylaw type for being adopted by municipalities. There are few isolated municipalities which have this type of ordinances, with different grade of legal restrictions, such as Sant Cugat del Vallès, Badalona, Montmeló and Barberà del Vallès (province of Barcelona), Torreblanca (prov. Castellón) and Mazarrón (prov. Murcia).

\section{Control measures}

Just as surveillance, in Spain the control plans are not systematised or standardised. Many municipalities have outsourced the mosquitoes control, but the specific training and experience, on tiger mosquito control, of the awarded companies is very variable.

The main mosquito control programs have been developed in Catalonia. For example, in the Baix Llobregat comarca (county), the integrated vector management includes community-based information plans and application of larvicides and adulticides [75]. In Sant Cugat del Vallés, Abramides et al. [76] combined four control measures, including application of larvicides and adulticides, public cooperation for source removal and cleaning of landfills, finding a significant reduction of oviposition. From 2008 to 2010, a massive campaign for sourcereduction was carried out in the same municipality, including door-to-door visits and interviews to residents [77]. This campaign allowed to inform the local population, to identify larval habitats, to measure resident's perception of the problem and achieved the involvement of citizens in control. In this reference the more usual breeding sites in houses are described: domestic drains (27.8\%), man-made ponds or pools without chlorine (26.7\%), drums (25.6\%), solid waste (12.9\%), flowerpot saucers $(9.8 \%)$, small objects (toys, ashtrays, pet water bowl) (9.8\%), ornamental fountains (9.8\%), other receptacles $(8.3 \%)$. Also, in public spaces of Catalonia the storm drains are very important places for control not just because they are frequently positives, but also because contain many larvae by $\mathrm{ml}$. Nevertheless, the first searches carried out in Murcia to locate larvae in the storm drains have been unsuccessful. Finally, non artificial breeding sites, as holes in trees, are very scarce, although it seems more abundant in the recent times, maybe due to the higher densities in Catalonia.

Also, some tests of biocides have been conducted in Spain. Bengoa et al. tested residual pyrethroids on plants 
to act as chemical barrier against adults [75] and ultralow volume (ULV) method with pyrethroids [78]. Both tests resulted in effective outcomes. Eritja [79] successfully tested the combination of Bacilus thuringensis israelensis and B. sphaericus, VBC60035 (Vectomax ${ }^{\mathrm{Tm}}$ FG), as larvicide in simulated catch basins, a common urban larval habitat. In 2013, a laboratory test with encapsulated adulticides (INESFLY ${ }^{\circ}$ ) was carried out in the University of Zaragoza and the three used formulations (5A IGR NG, 5A IGR, 5D IGR) (IGR = insect growth regulator) were $100 \%$ effective [80]. This method is not used extensively against Ae. albopictus in Spain yet, although similar products of this company are used against other insects (http://www.inesfly.com/index.php/es/proyectos-inesflymundo/category/espana-2).

The oil of lemon eucalyptus was tested as larvicide for control of Ae. albopictus, showing not to be applicable due to its high toxicity for non-target aquatic species as mosquitofish and frog tadpoles [81].

\section{Conclusion}

Ten years after the first record of Ae. albopictus this species is, unfortunately, well established and expanding along the Spanish Mediterranean Coast and we fear that there is a high risk that the Atlantic coast to be also colonized. As has been observed in several invaded countries, this species has high ecological adaptability and will settle down in more areas than it was expected, such as the early data of incomplete samplings of 2015 show. Increasing range of distribution, and positive localisations inside it, of Ae. albopictus in Spain (including the Balearic archipelago), as well as the high detection of imported cases of viruses such as dengue and chikingunya and other arboviruses, depict an alarming scenario where implementation of preventive and coordinated measures among all implicated actors appear as the most reasonable tool. Active and urgent reaction is therefore needed from central, regional and local governments to face the public health risk posed by the presence of the Asian tiger mosquito. In this sense, the future standardisation of sampling and control techniques among researchers, local administrations and policymakers, and extent them to entire territory with appropriate budget, favoured by the umbrella of a national strategy for managing Ae. albopictus would be, in our opinion, the main milestone for the next five years.

\section{Additional file}

Additional file 1: Historical record of the first detections of Aedes albopictus in municipalities of Spain. The bibliographical reference is included or it is considered as new record if this information was still unpublished. The reference number is related to the list of references of main document. (PDF $169 \mathrm{~kb}$ )

\section{Competing interests}

The authors declare that they have no competing interests.

\section{Authors' contributions}

FC structured the first version of the manuscript and compile the main information. All co-authors critically reviewed and approved the manuscript. FC, SD, PMAE, JAD and MB sampled in 2014. ATS compiled and processed the unpublished data form Catalonia. FC and IRA made the maps of distribution. All authors read and approved the final version of the manuscript

\section{Acknowledgements}

Part of the samplings are supported by the contract "Entomological surveillance at airports and ports against imported vectors of exotic infectious diseases and surveillance of potential indigenous vectors of such diseases", funding by the Spanish Ministery of Health, Social Services and Equality, and the project "The tiger mosquito invasion in Spain: A public health risk caused by global change", funding by the Spanish Ministry of Economy and Competitiveness. The Generalitat de Catalunya has provided their unpublished sampling data from 2011 to 2014, what was indispensable to complete the known distribution. The Instituto Universitario de Enfermedades Tropicales y Salud Pública de Canarias is involved in the entomological surveillance of airports and harbours of Canary Islands and the regional administration (Consejería de Sanidad) supports, in part, this work. The companies Compañía de Tratamientos de Levante S.L., Rafaela Belmonte Nortes and Campos Serrano Biólogos have collaborated in the samplings of 2014 in the Spanish Mediterranean side, exclusive Catalonia. The data of the project Atrapaeltigre.com has significantly helped to find some possible new localities for Ae. albopictus located far way from the known range.

\section{Author details}

'Departamento de Zoología y Antropología Física, Facultad de Biología Universidad de Murcia, Murcia, Spain. 'Departamento de Patología Animal, Facultad de Veterinaria, Universidad de Zaragoza, Zaragoza, Spain.

${ }^{3}$ Department d'Agricultura, Servei de Gestió Forestal, Direcció General del Medi Natural i Biodiversitat, Ramaderia, Pesca, Alimentació i Medi Natural, Barcelona, Spain. ${ }^{4}$ Servei de Control de Mosquits, Consell Comarcal del Baix Llobregat, Parc Torreblanca, Sant Feliu de Llobregat, Spain. ${ }^{5}$ Departament de Biologia, Área de Zoología, Universitat de les Illes Balears, Palma de Mallorca, Spain. ${ }^{6}$ Unidad de Entomología Médica, Servicio de Parasitología, Centro Nacional de Microbiología, Instituto de Salud Carlos III, Madrid, Spain.

Received: 6 October 2015 Accepted: 6 December 2015

Published online: 23 December 2015

\section{References}

1. Adhami J, Reiter P. Introduction and establishment of Aedes (Stegomyia) albopictus Skuse (Diptera: Culicidae) in Albania. J Am Mosq Control Assoc 1998;14(3):340-3.

2. Medlock JM, Hansford KM, Versteirt V, Cull B, Kampen H, Fontenille D, et al. An entomological review of invasive mosquitoes in Europe. Bull Ent Res Forthcoming 2015;[27] doi:10.1017/S0007485315000103]

3. Aranda C, Eritja R, Roiz D. First record and establishment of the mosquito Aedes albopictus in Spain. Med Vet Entomol. 2006;20:150-2.

4. Schaffner F, Karch S. Premiere observation d'Aedes albopictus (Skuse, 1894) en France metropolitaine. Acad Sci Paris Sciences de la Vie. 2000;323:373-5.

5. Scholte EJ, Schaffner F. Waiting for the tiger: establishment and spread of Aedes albopictus mosquito in Europe. In: Takken W, Knols BGJ, editors. Emerging pests and vector-borne diseases in Europe. Wageningen: Wageningen Academic Publishers; 2007. p. 241-60.

6. Eritja R, Escosa R, Lucientes J, Marquès E, Molina R, Roiz D, et al. Worldwide invasion of vector mosquitoes: present European distribution and challenges for Spain. Biol Invasions. 2005;7:87-97.

7. Roiz D, Eritja R, Escosa R, Lucientes J, Marquès E, Melero-Alcíbar R, et al. A survey of mosquitoes breeding in used tires in Spain for the detection of imported potential vector species. J Vector Ecol. 2007:32(1):10-5.

8. Giménez N, Barahona M, Casasa A, Domingo A, Gavagnach M, Martí C. Llegada de Aedes albopictus a España: un nuevo reto para la salud pública. Gac Sanit. 2007;21:25-8.

9. Generalitat de Catalunya. Caracterització de la població del mosquit tigre asiàtic (Aedes albopictus) a Catalunya (2006) [Internet]. Barcelona: 
Departament de Medi Ambient i Habitatge, Direcció General del Medi Natural; 2006 [cited 2014 Dic 1]. Available from: http://www.gencat.cat/ mediamb/fauna/memoria_aedes_06.pdf.

10. Generalitat de Catalunya. Caracterització de la població del mosquit tigre asiàtic (Aedes albopictus) a Catalunya 2008 [Internet]. Barcelona: Departament de Medi Ambient i Habitatge, Direcció General del Medi Natural; 2008 [cited 2014 Dic 1]. Available from: http://premsa.gencat.cat/pres_fsvp/docs/2010/10/ 29/13/29/3a2c0857-53da-4e38-a060-102e63e56544.pdf.

11. Roiz D, Eritja R, Melero-Alcibar R, Molina R, Marquès E, Ruiz S, et al. Distribución de Aedes (Stegomyia) albopictus (Skuse, 1894) (Diptera: Culicidae) en España. Bol SEA. 2007;40:523-6.

12. Roiz D, Eritja R, Molina R, Melero-Alcibar R, Lucientes J. Initial distribution assessment of Aedes albopictus (Diptera: Culicidae) in the Barcelona, Spain. Area J Med Entomol. 2008;45(3):347-52.

13. Comissió Interinstitucional per a la Prevenció i Control del Mosquit Tigre a Catalunya. Estratègia per a la prevenció i el control del mosquit tigre a Catalunya [Internet]. Barcelona: Departament de Salut, Generalitat de Catalunya; 2011 [cited 2014 Dic 1]. Available from: http://www.aspb.cat/ quefem/docs/Estrategia_mosquit_tigre_2011.pdf.

14. Bueno-Marí R, García-Mújica P, Rico-Miralles J, Agulló-Ronco A. Nuevos datos sobre el proceso de expansión de Aedes albopictus (Skuse, 1894) (Diptera, Culicidae) por el sureste de la Península Ibérica: hallazgo de la especie en Mazarrón (Murcia, España). Bol SEA. 2012;51:307-9.

15. Bueno-Marí R, Bernués-Bañeres $A$, Muñoz-Rodríguez M, Jiménez-Peydró R. Primera cita de Aedes albopictus (Skuse, 1894) en la provincia de Valencia (Diptera, Culicidae). Bol Asoc esp Entomol. 2013;37(3-4):375-8.

16. Bueno-Marí R, Acosta-Aleixandre R, Serna-Mompeán JP. Primeras capturas de Aedes albopictus (Skuse, 1894) (Diptera: Culicidae) en el Área Metropolitana de Valencia. Arquivos Entomoloxicos. 2014;12:103-8.

17. Bueno-Marí R, Lluch-Escribano JA, Gambín-Molina B. Primer registro de Aedes albopictus (Skuse, 1894) en la Mancomunidad de l'Alacantí. Acciones para evitar su dispersión. Cuadernos de Biodiversidad. 2014;44:12-6.

18. Bueno-Marí R, Martínez-Sanchís JA, Nájar-Sellés L. Arribada d'una nova espècie invasora a la comarca de la Marina Alta: Primeres troballes de mosquit tigre (Aedes albopictus (Skuse, 1894)). Aguaits. 2014;34:117-23.

19. Bueno Marí R, Jiménez-Peydró R. La creciente amenaza de las invasiones biológicas de mosquitos sobre la salud pública española. Enferm Emerg. 2009;11(1):30-5.

20. Bueno Marí R, Jiménez-Peydró R. Aedes albopictus (Skuse, 1894): situación actual y registros de una importante especie de mosquito invasora en España. B Malariol Salud Amb. 2010;50(1):139-43.

21. Bueno-Marí $R$, Jiménez-Peydró R. ¿Pueden la malaria y el dengue reaparecer en España? Gac Sanit. 2010;24(4):347-53.

22. Bueno-Marí R, Jiménez-Peydró R. Situación actual en España y ecoepidemilogía de las arbovirosis transmitidas por mosquitos culícidos (Diptera: Culicidae). Rev Esp Salud Pública. 2010;84(3):255-69.

23. Bueno-Marí R, Jiménez-Peydró R. Implicaciones sanitarias del establecimiento y expansión en España del mosquito Aedes albopictus. Rev Esp Salud Pública. 2012;86(4):319-30.

24. Delacour S, Alarcón-Elbal P, Bengoa M, Melero-Alcíbar R, Pinal R, RuizArrondo I, et al. Aedes (Stegomyia) albopictus (Skuse, 1894), primera cita en Torrevieja (Alicante). Bol SEA. 2009;45:518.

25. Delacour S, Barandika JF, García-Pérez AL, Collantes F, Ruiz-Arrondo I, Alarcón-Elbal PM, et al. Detección temprana del mosquito tigre, Aedes albopictus (Skuse, 1894), en el País Vasco (España). An Biol. 2015;37:25-30.

26. Delacour-Estrella S, Bravo-Minguet D, Alarcón-Elbal PM, Bengoa M, Casanova A, Melero-Alcibar R, et al. Detección de Aedes (Stegomyia) albopictus (Skuse, 1894) (Diptera: Culicidae) en Benicàssim. Primera cita para la provincia de Castellón (España). Bol SEA. 2010;47:440

27. Delacour-Estrella S, Collantes F, Ruiz-Arrondo I, Alarcón-Elbal PM, Delgado JA, Eritja R, et al. Primera cita de mosquito tigre, Aedes albopictus (Diptera, Culicidae), para Andalucía y primera corroboración de los datos de la aplicación Tigatrapp. An Biol. 2014;36:93-6.

28. Alarcón-Elbal PM, Delacour S, Pinal R, Ruiz-Arrondo I, Muñoz A, Bengoa M, et al. Establecimiento y mantenimiento de una colonia autóctona española de Aedes (Stegomyia) albopictus Skuse, 1894, (Diptera, Culicidae) en laboratorio. Parasitol Latinoam. 2010;69(2):140-8.

29. Alarcón-Elbal PM, Delacour-Estrella S, Collantes F, Delgado JA, Ruiz-Arrondo I, Pinal-Prieto R, et al. Primeros hallazgos de Aedes (Stegomyia) albopictus (Skuse, 1894) en la provincia de Valencia, España. An Biol. 2013;35:95-9.
30. Alarcón-Elbal PM, Delacour-Estrella S, Ruiz-Arrondo I, Collantes F, Delgado JA, Morales-Bueno J, et al. Updated distribution of Aedes albopictus (Diptera: Culicidae) in Spain: new findings in the mainland Spanish Levante, 2013. Mem Inst Oswaldo Cruz. 2014;109(6):782-6.

31. Collantes F, Delgado JA. Primera cita de Aedes (Stegomyia) albopictus (Skuse, 1894) en la Región de Murcia. An Biol. 2011;33:99-101.

32. Miquel M, del Río R, Borràs D, Barceló C, Paredes-Esquivel C, Lucientes J, et al. First detection of Aedes albopictus (Diptera: Culicidae) in the Balearic Islands (Spain) and assessment of its establishment according to the ECDC guidelines. JEMCA. 2013;31:8-11.

33. Lucientes-Curdi J, Molina-Moreno R, Amela-Heras C, Simon-Soria F, SantosSanz S, Sánchez-Gómez A, et al. Dispersion of Aedes albopictus in the Spanish Mediterranean Area. Eur J Public Health. 2014;24(4):637-40.

34. Barceló C, Bengoa M, Monerris M, Molina R, Delacour-Estrella S, Lucientes J, et al. First record of Aedes albopictus (Skuse, 1894) (Diptera; Culicidae) from Ibiza (Balearic Islands; Spain). JEMCA. 2015;33:1-4.

35. European Centre for Disease Prevention and Control (ECDC). Guidelines for the surveillance of invasive mosquitoes in Europe. ECDC Technical Report [Internet]. Stockholm: ECDC; 2012 [cited 2014 Dic 1]. Available from: http://ecdc.europa. eu/en/publications/Publications/TER-Mosquito-surveillance-guidelines.pdf.

36. World Health Organization, European Mosquito Control Association. Guidelines for the control of invasive mosquitoes and associated vector borne diseases on the European continent. First Draft. 2011. Available from: http://www.emcaonline.eu/documents/visitors/EMCA_guidelines_Speyer_2011.pdf.

37. Kampen $\mathrm{H}$, Medlock JM, Vaux AGC, Koenraadt CJM, van Vliet AJH, Bartumeus F et al. Approaches to passive mosquito surveillance in the EU. Parasit Vectors 2015;8:9 [13] doi:10.1186/s13071-014-0604-5.

38. European Centre for Disease Prevention and Control (ECDC). Guidelines for the surveillance of native mosquito species in Europe. ECDC Technical Report [Internet]. Stockholm: ECDC; 2014, Sweden; 2014 [cited 2014 Dic 1]. Available from: http://ecdc.europa.eu/en/publications/Publications/ surveillance-of\%20native-mosquitoes\%20-guidelines.pdf.

39. Centro de Coordinación de Alertas y Emergencias Sanitarias (CCAES). Trabajo técnico sobre vigilancia entomológica en aeropuertos y puertos frente a vectores importados de enfermedades infecciosas exóticas, y vigilancia de potenciales vectores autóctonos de dichas enfermedades [Internet]. Madrid: Ministerio de Sanidad, Servicios Sociales e Igualdad; 2013 [cited 2014 Dic 1]. Available from: http://www.msssi.gob.es/profesionales/ saludPublica/ccayes/alertasActual/docs/Vigilancia_Entomologica_2013_ ResumenEjecutivo_Final.pdf.

40. Collantes F, Delgado JA, Alarcón-Elbal PM, Delacour S, Lucientes J. First confirmed outdoor winter reproductive activity of Asian tiger mosquito (Aedes albopictus) in Europe. An Biol. 2014;36:71-6.

41. Roche B, Léger L, L'Amber G, Lacour G, Foussadier R, Besnard G, et al. The spread of Aedes albopictus in metropolitan France: Contribution of environmental drivers and human activities and predictions for a near future. PLOS ONE. 2015;10(5), e0125600. doi:10.1371/journal.pone.0125600 [13].

42. Moore CG, Mitchell CJ. Aedes albopictus in the United States: Ten-Year presence and public health implications. Emerg Infect Dis. 1997:3(3):329-34. doi:10.3201/eid0303.970309.

43. Muñoz J, Eritja R, Alcaide M, Montalvo T, Soriguer RC, Figuerola J. Hostfeeding patterns of native Culex pipiens and invasive Aedes albopictus mosquitoes (Diptera: Culicidae) in urban zones from Barcelona, Spain. J Med Entomol. 2011;48(4):956-60.

44. Cancrini G, Frangipane di Regalbono A, Ricci I, Tessarin C, Gabrielli S, Pietrobelli M. Aedes albopictus is a natural vector of Dirofilaria immitis in Italy. Vet Parasitol. 2003;118(3-4):195-202.

45. Gratz NG. Critical review of the vector status of Aedes albopictus. Med Vet Entomol. 2004;18(3):215-27.

46. Calzolari $M$, Zé-Zé $L$, Růžek $D$, Vázquez $A$, Jeffries $C$, Defilippo $F$, et al. Detection of mosquito-only flaviviruses in Europe. J Gen Virol. 2012;93(6):1215-25. doi:10.1099/vir.0.040485-0.

47. Paupy C, Delatte H, Bagny L, Corbel V, Fontenille D. Aedes albopictus, an arbovirus vector: from the darkness to the light. Microbes Infect. 2009;11(14-15):1177-85. doi:10.1016/j.micinf.2009.05.005.

48. Aranda C, Sánchez-Seco MP, Cáceres F, Escosa R, Gálvez JC, Masià M, et al. Detection and monitoring of mosquito flaviviruses in Spain between 2001 and 2005. Vector Borne Zoonotic Dis. 2009;9(2):171-8. doi:10.1089/vbz.2008.0073.

49. Bonizzoni M, Gasperi G, Chen X, James AA. The invasive mosquito species Aedes albopictus: current knowledge and future perspectives. Trends Parasitol. 2013;29(9):460-7. 
50. Institut de Veille Sanitaire (INVS). Chikungunya et dengue-Données de la surveillance renforcée en France métropolitaine en 2014 [Internet]. SaintMaurice: INVS; 2014 [cited 2015 Jan 15]. Available from: http://www.invs. sante.fr/Dossiers-thematiques/Maladies-infectieuses/Maladies-a-transmissionvectorielle/Chikungunya/Donnees-epidemiologiques/France-metropolitaine/ Chikungunya-et-dengue-Donnees-de-la-surveillance-renforcee-en-Francemetropolitaine-en-2014.

51. Delisle E, Rousseau C, Broche B, Leparc-Goffart I, L'Ambert G, Cochet A, et al. Chikungunya outbreak in Montpellier, France, September to October 2014. Euro Surveill. 2015;20(17). Available from: http://www.eurosurveillance.org/ ViewArticle.aspx?Articleld=21108

52. Cancrini G, Romi R, Gabrielli S, Toma L, Di Paolo M, Scaramozzino P. First finding of Dirofilaria repens in a natural population of Aedes albopictus. Med Vet Entomol. 2003;17:448-51.

53. Centro de Coordinación de Alertas y Emergencias Sanitarias (CCAES). Evaluación del riesgo de introducción y circulación del virus de dengue en España [Internet]. Madrid: Ministerio de Sanidad, Servicios Sociales e Igualdad; 2013 [cited 2014 Dic 1]. Available from: http://www.msssi.gob.es/ profesionales/saludPublica/ccayes/analisisituacion/doc/evRiDe_5_13.pdf.

54. Santos-Sanz S, Sierra-Moros MJ, Oliva-Iñiguez L, Sanchez-Gómez A, Suarez-Rodriguez B, Simón-Soria F, et al. Posibilidad de introducción y circulación del virus del dengue en España. Rev Esp Salud Pública. 2014;88:555-67.

55. Amador-Prousa C, López-Perezagua MM, Arjona Zaragozí FJ, MartínezPeinado C. Infección por virus de Chikungunya en una viajera española. Med Clin (Barc). 2007;129(3):116-9.

56. Centro de Coordinación de Alertas y Emergencias Sanitarias (CCAES). Brote de fiebre Chikungunya en la Región de las Américas Evaluación Rápida de Riesgo para España. [Internet]. Madrid: Ministerio de Sanidad, Servicios Sociales e Igualdad; 2014 [cited 2014 Dic 1]. Available from: http://www. msssi.gob.es/profesionales/saludPublica/ccayes/alertasActual/docs/ Chikungunya_24.06.2014.pdf.

57. PAHO. Number of Reported Cases of Chikungunya Fever in the Americas, by Country or Territory 2013-2014 Cumulative cases (Updated at 23 October 2015) [Internet]. Washington: PAHO; 2015 [cited 2015 October 23]. Available from: http://www.paho.org/hq/index.php?option=com_docman\&task=doc_ download\&ltemid=270\&gid=30198\&lang=en.

58. Requena-Méndez A, García C, Aldasoro E, Vicente JA, Martínez MJ, PérezMolina JA, et al. Cases of chikungunya virus infection in travellers returning to Spain from Haiti or Dominican Republic, April-June 2014. Euro Surveill. 2014;19(28). Available online: http://www.eurosurveillance.org/ViewArticle. aspx?Articleld=20853.

59. Paty MC, Six C, Charlet F, Heuzé G, Cochet A, Wiegandt A, et al. Large number of imported chikungunya cases in mainland France, 2014: a challenge for surveillance and response. Euro Surveill. 2014;19(28). Available from: http://www.eurosurveillance.org/ViewArticle.aspx?Articleld=20856,

60. Velasco E, Cimas M, Díaz, O. Enfermedad por virus chikungunya en España. Bol Epidem Semanal. 2014; 22(16): 2019-226. Available online: http://revista. isciii.es/index.php/bes/article/download/914/1105.

61. Real Decreto 2210/1995, de 28 de diciembre, por el que se crea la red nacional de vigilancia epidemiológica. Madrid: Boletín Oficial del Estado 21; 1995: 2153-58. Available from: http://www.boe.es/buscar/doc.php?id=BOEA-1996-1502.

62. Consejo Interterritorial del Sistema Nacional de Salud. Protocolos de las enfermedades de declaración obligatoria [Internet]. Madrid: Minsiterio de Sanidad, Servicios Sociales e Igualdad; 2013 [cited 2014 Dic 1]. Available from: http://www.isciii.es/ISCIII/es/contenidos/fd-servicios-cientifico-tecnicos/ fd-vigilancias-alertas/PROTOCOLOS_RENAVE.pdf.

63. Orden SSI/445/2015, de 9 de marzo, por la que se modifican los anexos I, II y III del Real Decreto 2210/1995, de 28 de diciembre, por el que se crea la Red Nacional de Vigilancia Epidemiológica, relativos a la lista de enfermedades de declaración obligatoria, modalidades de declaración y enfermedades endémicas de ámbito regional. Madrid: Boletín Oficial del Estado 65; March 2015: 24012-15. Available from: http://www.boe.es/ buscar/doc.php?id=BOE-A-2015-2837.

64. Degallier N, Favier C, Boulanger JP, Menkes C. Imported and autochthonous cases in the dynamics of dengue epidemics in Brazil. Rev Saúde Pública. 2009:43(1):1-7.

65. Huang X, Williams G, Clements ACA, Hu W. Imported dengue cases, weather variation and autochthonous dengue incidence in Cairns, Australia. PLOS ONE 2013; 8(12): e81887 [7]. doi:10.1371/journal.pone.0081887.
66. Scott TW, Morrison AC. Aedes aegypti density and the risk of dengue virus transmission. In: Takken W, Scott TW, editors. Ecological aspects for application of genetically modified mosquitoes. Dordrecht: FRONTIS; 2003. p. 187-206. Available from: http://library.wur.nl/ojs/index.php/frontis/article/ view/849.

67. Halasa YA, Shepard DS, Wittenberg E, Fonseca DM, Farajollahi A, Healy S, et al. Willingness-to-pay for an area-wide integrated pest management program to control the Asian tiger mosquito in New Jersey. J Am Mosq Control Assoc. 2012;28(3):225-36.

68. Halasa YA, Shepard DS, Fonseca DM, Farajollahi A, Healy S, Gaugler R, et al Quantifying the impact of mosquitoes on quality of life and enjoyment of yard and porch activities in New Jersey. PLOS ONE 2014;9(3): e89221 [9] doi:10.1371/journal.pone.0089221

69. Worobey J, Fonseca DM, Espinosa C, Healy S, Gaugler A. Child outdoor physical activity is reduced by prevalence of the Asian tiger mosquito, Aedes albopictus. J Am Mosq Control Assoc. 2013;29(1):78-80.

70. Curcó N. Mosquito tigre: repercusiones de su llegada a España. Piel. 2007;22(5):238-42

71. Curcó N, Giménez N, Serra M, Ripoll A, García M, Vives P. Picaduras por mosquito tigre. Percepción de la población afectada tras el establecimiento de Aedes albopictus en España. Actas Dermo-Sifiliográficas. 2008;99(9):708-13.

72. Guasch VM. Caracterització de la població de mosquit tigre asiàtic (Aedes albopictus) al municipi de Rubí i anàlisi del impacte ambiental associat en el medi socioeconòmic. End-of-career project. Barcelona: Universitat Autònoma de Barcelona; 2009. Available from: http://ddd.uab.cat/record/ 69649.

73. Real Decreto 630/2013, de 2 de agosto, por el que se regula el Catálogo español de especies exóticas invasoras. Madrid: Boletín Oficial del Estado 185; August 2013: 56764-86. Available from: http://www.boe.es/buscar/doc. php?id=BOE-A-2013-8565.

74. Conn DB. Aquatic invasive species and emerging infectious disease threats: A One Health perspective. Aquatic Invasions. 2014;9(3):383-90.

75. Bengoa M, Eritja R, Lucientes J. Laboratory tests of the residual effect of deltamethrin on vegetation against Aedes albopictus. J Am Mosqu Control Assoc. 2013;29(3):284-8.

76. Abramides GC, Roiz D, Guitart R, Quintana S, Guerrero I, Giménez N. Effectiveness of a multiple intervention strategy for the control of the tiger mosquito (Aedes albopictus) in Spain. T Roy Soc Trop Med H. 2011;105:281-8.

77. Abramides GC, Roiz D, Guitart R, Quintana S, Giménez N. Control of the Asian tiger mosquito (Aedes albopictus) in a firmly established area in Spain: risk factors and people's involvement. T Roy Soc Trop Med H. 2013;107:1-9.

78. Bengoa M, Eritja R, Lucientes J. Ground ultra-low volume adulticiding field trials using pyrethroids against Aedes albopictus in the Baix Llobregat region, Spain. J Am Mosqu Control Assoc. 2014;30(1):42-50.

79. Eritja R. Laboratory tests on the efficacy of VBC60035, a combined larvicidal formulation of Bacillus thuringiensis israelensis (strain AM65-52) and Bacillus sphaericus (strain 2362) against Aedes albopictus in simulated catch basins. J Am Mosqu Control Assoc. 2013:29(3):280-3.

80. Oropeza V, Pinal R, Mateo P, Delacour-Estrella S, Alarcón-Elbal PM, Ruiz Arrondo I, et al. La eficacia residual de tres formulaciones de pinturas insecticidas (tecnologia INESFLY ${ }^{\circledR}$ ) sobre diferentes tipos de superficies, para el control de Aedes (Stegomya) albopictus Skuse,1894 en condiciones de laboratorio. In: VIII Congreso Nacional de Entomología Aplicada / XIV Jornadas Científicas de la Sociedad Española de Entomología Aplicada (SEEA). Mataró; Madrid: Sociedad Española de Entomología Aplicada; 2013. p. 252. panel 81.

81. Escartin S, Mariani S. Evaluating the toxicity of oil of lemon eucalyptus, Corymbia citriodora (Hook.), against larvae of the Asian tiger mosquito and non-target fish and larval amphibians. An Biol. 2014;36:97-105. 